\title{
Ovitrap Surveillance of Aedes aegypti and Aedes albopictus in Dengue Endemic Areas in Keramat and Shah Alam, Selangor in 2016
}

Noor Afizah $A^{a}$, Mohd Arif $A K^{a}$, Nazni $W A^{a}$ and Lee $H L^{a}$

${ }^{a}$ Medical Entomology Unit, WHO Collaborating Centre for the Ecology, Taxonomy and Control of Vectors

of Malaria, Filariasis \& Dengue, Institute for Medical Research, Jalan Pahang, WPKL 50588, Kuala Lumpur

\section{ABSTRACT}

Introduction: Entomological surveillance is crucial to determine the abundance of dengue vector and to evaluate breeding areas of Aedes aegypti and Aedes albopictus. The objective of this study is to determine the distribution and breeding preference for both Ae. aegypti and Ae. albopictus in dengue endemic areas. Materials and Methods: Ovitraps surveillance was conducted in two dengue endemic areas; AU2, Keramat and Seksyen 7, Shah Alam, Selangor. A minimum number of 100 ovitraps were deployed for 5 days in the study sites. Samples collected were brought back to the lab and all larvae recovered were identified to species level. Results: The ovitap index (OI) in both localities exceeded the transmission threshold of $10 \%$ with the OI recorded ranged from 42.3-79.8\% in AU2, Keramat and 16.7-42.9\% in Seksyen 7, Shah Alam. Ae. albopictus was the dominant species in AU2 Keramat with the highest ratio Ae. aegypti to Ae. albopictus recorded was 1.00:22.79. Nonetheless, in Seksyen 7, Shah Alam the difference in Ae. aegypti to Ae. albopictus ratio is not really prominent with 1.00:3.61 for ovitraps deployed outdoor and 3.40:1.00 for ovitraps set indoor. It was determined that single infestation of either Ae. aegypti or Ae. albopictus is more frequent for ovitraps deployed indoor and/or outdoor, respectively. It was also determined that mixed infestations were found in this study indicating that both species can oviposit in the same container. Conclusion: This study indicates that $\mathrm{Ol}$ is still above transmission threshold in both study sites. While Ae. aegypti and Ae. albopictus remain as a dominant indoor and outdoor breeder, respectively, mixed breeding of Aedes species in a same container was also observed.

KEYWORDS : Ovitraps, surveillance, Aedes aegypti, Aedes albopictus, dengue

\section{INTRODUCTION}

Dengue fever is an important arthropod-borne viral diseases in the world particularly in tropical regions. ${ }^{1}$ In the past, major outbreaks of dengue cases were reported in many countries, causing morbidity and mortality and it is a global public health concern. ${ }^{2-4}$ During the past five decades, the incidence rate of dengue has increased up to 30 folds worldwide. It was estimated that 50 to 100

Corresponding author:

Noor Afizah Ahmad

Medical Entomology Unit,

WHO Collaborating Centre for the Ecology, Taxonomy and Control of Vectors of Malaria, Filariasis \& Dengue, Institute for Medical Research, Jalan Pahang, WPKL 50588, Kuala Lumpur

Tel : +60326162687

Email : afizah@imr.gov.my million new infections occur yearly in more than 100 endemic countries. ${ }^{5}$ In Malaysia, dengue is endemic and according to the report by the Ministry of Health $(\mathrm{MOH})$, the cumulative numbers of dengue fever cases till the 51 week of 2017 were 82,840 cases and 171 dengue-related deaths were recorded in $2017 .^{6}$ Dengue was mainly transmitted by Aedes aegypti and Aedes albopictus. Ae. aegypti prefer clean stagnant water which can be found inside artificial containers and near to human residences while Ae. albopictus breed in natural containers and also outdoor man-made containers. ${ }^{7,8}$ In several regions of Malaysia, studies reported mixed infestation of two species in the same breeding containers. ${ }^{9-12}$

Vector surveillance through ovitraps is a good and cost effective tool for dengue surveillance. It is reported that ovitrapping is a more efficient tool to 
detect the presence of Aedes as compared to larval survey when the infestation rate was low. 13-15 Ovitrap surveillance can provide the information of dengue outbreak forecast particularly in the regions of minor Aedes mosquito invasion. ${ }^{16,17}$ In this study, a series of ovitrapping activities was conducted to investigate the abundance and distribution of $\mathrm{Ae}$. aegypti and Ae. albopictus population in the dengue endemic areas.

\section{Materials and methods}

\section{Study sites}

The study was conducted in two residential areas which were in AU2, Keramat and in Seksyen 7, Shah Alam in Selangor (Fig. 1). Localities were chosen since the locations were identified as dengue hotspot areas as suggested by the Ministry of Health $(\mathrm{MOH})$ Malaysia. Both sites were identified as the sub-urban and urban residential areas during study period. The areas had appropriate drainage system and high dense vegetation surrounding the areas. (Table 1)
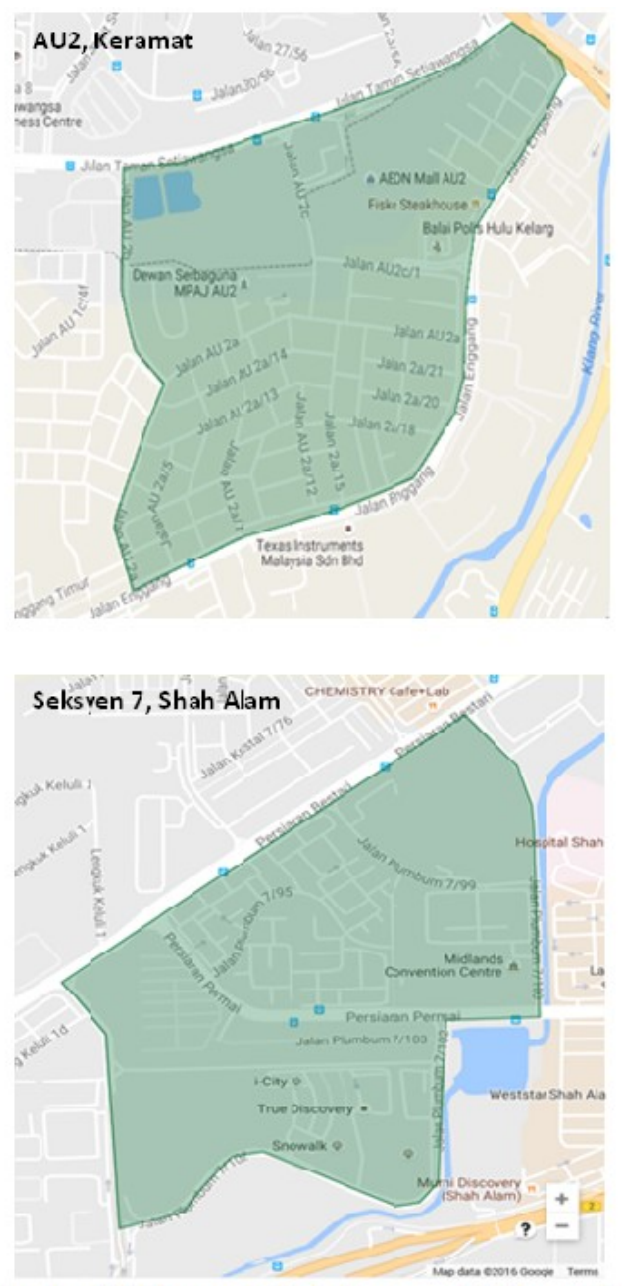

Figure 1 Sampling site AU2, Keramat and in Seksyen 7, Shah Alam
Table 1 The study localities in AU2, Keramat and Seksyen 7, Shah Alam

\begin{tabular}{|c|c|c|c|c|}
\hline Locality & $\begin{array}{l}\text { GPS } \\
\text { Coordinate }\end{array}$ & Category & $\begin{array}{l}\text { Houses/ } \\
\text { Residential } \\
\text { Type }\end{array}$ & $\begin{array}{l}\text { Ecological } \\
\text { condition }\end{array}$ \\
\hline \multirow[t]{2}{*}{$\begin{array}{l}\text { AU2, } \\
\text { Keramat }\end{array}$} & \multirow[t]{2}{*}{$\begin{array}{l}3^{\circ} 10^{\prime} 24.0 " \mathrm{~N} \\
101^{\circ} 44^{\prime} 57.0^{\prime \prime} \mathrm{E}\end{array}$} & \multirow[t]{2}{*}{ Suburban } & \multirow[t]{2}{*}{$\begin{array}{l}\text { Planned } \\
\text { terraces }\end{array}$} & $\begin{array}{l}\text { Surrounded } \\
\text { with } \\
\text { various } \\
\text { vegetation } \\
\text { such as trees } \\
\text { and shrubs. }\end{array}$ \\
\hline & & & & $\begin{array}{l}\text { Well- } \\
\text { managed and } \\
\text { generally } \\
\text { clean area. }\end{array}$ \\
\hline \multirow[t]{2}{*}{$\begin{array}{l}\text { Seksyen 7, } \\
\text { Shah Alam }\end{array}$} & \multirow[t]{2}{*}{$\begin{array}{l}3^{\circ} 04^{\prime} 00.5^{\prime \prime N} \\
101^{\circ} 28^{\prime} 59.6 " \mathrm{E}\end{array}$} & \multirow[t]{2}{*}{ Urban } & \multirow[t]{2}{*}{$\begin{array}{l}\text { Planned } \\
\text { terraces }\end{array}$} & $\begin{array}{l}\text { Have some } \\
\text { area with } \\
\text { vegetation, } \\
\text { trees and } \\
\text { shrubs. }\end{array}$ \\
\hline & & & & $\begin{array}{l}\text { Well- } \\
\text { managed and } \\
\text { clean area. }\end{array}$ \\
\hline
\end{tabular}

\section{Ovitrap surveillance}

Ovitrapping was done to obtain baseline data of local wild mosquito population and it was conducted following the guidelines of $\mathrm{MOH}$. ${ }^{18}$ Black plastic containers of $300 \mathrm{~mL}$ volume was used as the ovitrap. Hard-board measuring $10 \mathrm{~cm} \times 2.5 \mathrm{~cm} \times 0.3$ $\mathrm{cm}$ was used as an oviposition paddle and was placed in the ovitrap container to allow mosquito to lay eggs on its surface. Clean tap water was added to a level of $5.5 \mathrm{~cm} .{ }^{19}$ In this study, indoor was referred to as the interior of the house and outdoor as outside the house. The ovitraps were recovered after 5 days of placing in designated areas and brought back to the Medical Entomology Unit laboratory, Institute for Medical Research (IMR) for the larvae species identification.

In AU2, Keramat; the sampling was completed after five independent trips (Table 2). For each trip, a total of 100 ovitraps were placed. 50 ovitraps were placed indoors and outdoors respectively for placement on $8^{\text {th }}$ August 2016 in randomly selected houses. Meanwhile, 100 ovitraps were placed outdoors for the remaining 4 placements, respectively. The surveillance at Seksyen 7, Shah Alam was also completed after four independent trips (Table 2). For each trip, a total of 100 ovitraps were randomly placed indoors and outdoors in selected houses. 
Table 2 Ovitrap Index (OI),percentage of Ae. aegyptiand Ae. albopictus for indoor and outdoor ovitrap and percentage of mixed breeding

\begin{tabular}{|c|c|c|c|c|c|c|c|c|}
\hline \multirow[b]{3}{*}{$\begin{array}{l}\text { Ovitrap } \\
\text { placement } \\
\text { trip }\end{array}$} & \multirow[b]{3}{*}{$\begin{array}{l}\text { Date trap } \\
\text { collected }\end{array}$} & \multirow[b]{3}{*}{$\begin{array}{l}\text { Ovitrap } \\
\text { Index (\%) }\end{array}$} & \multicolumn{6}{|c|}{ AU2, Keramat } \\
\hline & & & \multicolumn{3}{|c|}{ Indoor } & \multicolumn{3}{|c|}{ Outdoor } \\
\hline & & & $\begin{array}{c}\text { Ae. } \\
\text { aegypti } \\
(\%)\end{array}$ & $\begin{array}{c}A e . \\
\text { albopictus } \\
(\%)\end{array}$ & $\begin{array}{l}\text { Mixed } \\
\text { Breeding } \\
(\%)\end{array}$ & $\begin{array}{c}\text { Ae. } \\
\text { aegypti } \\
(\%)\end{array}$ & $\begin{array}{c}\text { Ae. } \\
\text { albopictus } \\
(\%)\end{array}$ & $\begin{array}{c}\text { Mixed } \\
\text { Breeding } \\
\text { (\%) }\end{array}$ \\
\hline $1^{\text {st }}$ Trip & 8-Aug-16 & 42.3 & 53.8 & 23.8 & 30.8 & 0 & 73.8 & 26.2 \\
\hline $2^{\text {nd }}$ Trip & 26-Sep-16 & 77.4 & $\mathrm{n} / \mathrm{a}$ & $\mathrm{n} / \mathrm{a}$ & $\mathrm{n} / \mathrm{a}$ & 2.8 & 79.1 & 18.1 \\
\hline $3^{\text {rd }}$ Trip & $10-0 c t-16$ & 62.7 & $\mathrm{n} / \mathrm{a}$ & $\mathrm{n} / \mathrm{a}$ & $\mathrm{n} / \mathrm{a}$ & 9.2 & 73.9 & 16.9 \\
\hline $4^{\text {th }}$ Trip & $24-O c t-16$ & 67.0 & $\mathrm{n} / \mathrm{a}$ & $\mathrm{n} / \mathrm{a}$ & $\mathrm{n} / \mathrm{a}$ & 2.9 & 79.7 & 17.4 \\
\hline \multirow[t]{2}{*}{$5^{\text {th }}$ Trip } & 27-Feb-17 & 79.8 & $\mathrm{n} / \mathrm{a}$ & $\mathrm{n} / \mathrm{a}$ & $\mathrm{n} / \mathrm{a}$ & 0 & 78.5 & 21.5 \\
\hline & & & \multicolumn{6}{|c|}{ Seksyen 7, Shah Alam } \\
\hline $1^{\text {st }}$ Trip & 29-Aug-16 & 29.8 & 50.0 & 0 & 50.0 & 38.5 & 42.3 & 19.2 \\
\hline $2^{\text {nd }}$ Trip & $17-O c t-16$ & 16.7 & 80.0 & 20.0 & 0 & 50.0 & 50.0 & 0 \\
\hline $3^{\text {rd }}$ Trip & $31-0 c t-16$ & 31.8 & 100.0 & 0 & 0 & 31.6 & 63.1 & 5.3 \\
\hline $4^{\text {th }}$ Trip & 14-Nov-16 & 42.9 & 66.7 & 16.6 & 16.7 & 29.6 & 48.2 & 22.2 \\
\hline
\end{tabular}

\section{Identification of larvae}

The contents of ovitrap were transferred into plastic containers, and the paddle was then placed into the container to allow eggs on it to hatch. The larvae were routinely fed on liver powder (BD Difco $^{T M}$, USA) and bovine liver chunk diet. Larvae identification was conducted when the larvae reached the L3 stage. All larvae were identified to species according to specific criteria ${ }^{20}$ and the number of larvae in each ovitrap were also recorded.

\section{Data analysis}

All the data were analyzed as follow:

a. Ovitrap index $(\mathrm{OI})=($ Number of positive traps / Number of recovered traps) $X 100 \%$

b. Mean larvae per ovitrap = Total number of larvae / Number of recovered ovitraps.

One-way ANOVA analysis was performed using SPSS (Version 19.0; IBM, Armonk, NY). The levels of statistical significance were resolute at $P=0.05$.

\section{Results}

\section{Ovitrap surveillance}

Table 2 shows the ovitrap index (OI), percentage of Ae. aegypti and Ae. albopictus for indoor and outdoor ovitraps and percentage of mixed breeding. The $\mathrm{Ol}$ in both localities exceeds the transmission threshold of $10 \%{ }^{21}$ and is summarized in Table 2 . In general, the $\mathrm{Ol}$ for $\mathrm{AU} 2$, Keramat were higher than Seksyen 7, Shah Alam (Fig. 2). The OI in AU2, Keramat and Seksyen 7, Shah Alam ranged from 42.3 $-79.8 \%$ and $16.7-42.9 \%$ respectively. Both sites recorded a higher percentage of single infestation of Ae. aegypti as compared to Ae. albopictus and/or mixed infestation for ovitraps deployed indoor. On the other hand, ovitraps that were set outdoor recorded a higher single infestation of Ae. albopictus than single infestation of Ae. aegypti and/or mixed infestation except for the 2nd placement trip at Seksyen 7, Shah Alam which recorded the same single infestation percentage for each species. Mixed infestation was consistently observed in ovitraps deployed outdoors but at a low percentage $(5.3 \%$ to 26.2\%). A non-consistent but a higher percentage (16.7\% to $50.0 \%$ mixed breeding was recorded indoors.

The total number of Aedes sp. larvae collected using ovitraps, mean number of larvae per recovered ovitrap and ratio of Ae. aegypti to Ae. albopictus collected at AU2, Keramat and Seksyen 7, Shah Alam is shown in Fig. 3 and Table 3 . In this study, a very high Ae. albopictus population was found in AU2, Keramat. A total of 12,707 Aedes larvae were collected using ovitraps, comprising of 11,625 Ae. albopictus and 1,082 Ae. aegypti which indicated the former population is about ten times higher than the latter. In each placement trip, more Ae. 
albopictus than Ae. aegypti were collected with the highest mean larvae per trap recorded was $33.57 \pm$ 3.64 with no significant difference observed among the placement trips $(p>0.05)$. Based on the ratio of Ae. aegypti to Ae. albopictus infestation outdoors, the latter was found to be a dominant outdoor breeder with the highest ratio of 1.00:22.79. Nonetheless, due to a limited data for indoor population, the comparison for infestation ratio cannot be made for indoor population for AU2, Keramat. Meanwhile, in Seksyen 7, Shah Alam, a total of 2,482 larvae comprising 1,119 Ae. albopictus and 1,363 Ae. aegypti were collected which indicated the population for both species in this locality was comparable. Similar trend was recorded in Shah Alam with Ae. albopictus dominating the outdoor traps with mean larvae per trap was $5.83 \pm 1.66$ with the highest ratio Ae. aegypti to Ae. albopictus breeding of 1.00:3.61. Ae. aegypti was the dominant indoor breeder with mean larvae per trap recorded of $19.74 \pm 7.43$ and the highest infestation ratio of Ae. aegypti to Ae. albopictus recorded indoor was 3.40:1.00.

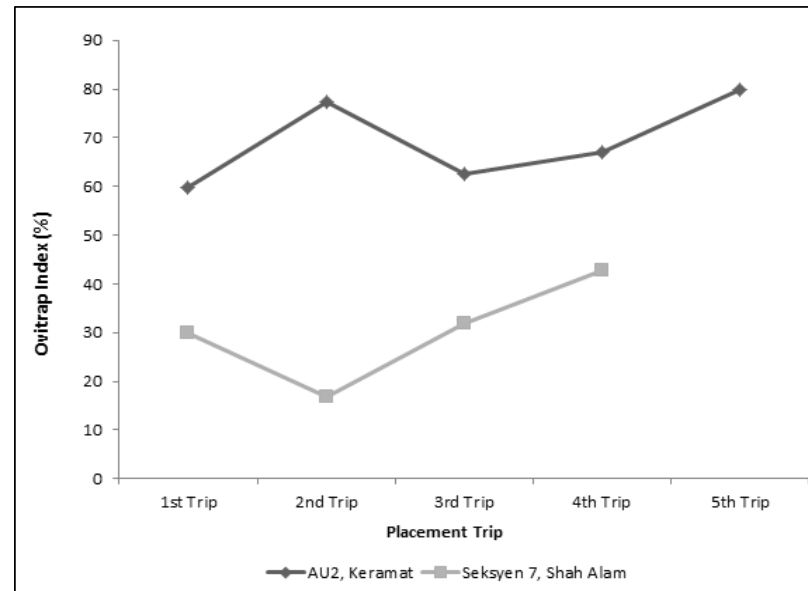

Figure 2 Ovitrap index in AU2, Keramat and Seksyen 7, Shah Alam

\section{Discussion and Conclusion}

This study utilized ovitrapping technique for Aedes surveillance purpose and has been reported as an economical and effective tool as compared to larval survey especially when the Aedes infestation rate is low. The cryptic breeding sites of dengue vectors makes the conventional larval survey technique less sensitive and less efficient. ${ }^{13-15}$ Based on the total number of Aedes species collected during this study, it was found that Ae. albopictus population is highly abundant and dominated the area in AU2, Keramat. This species is significantly dominating the ovitraps deployed outdoors in line with many ovitrap surveillance studies which reported Ae. albopictus as an outdoor breeder. ${ }^{10,22,23}$ The high population of Ae. albopictus in this site may be due to the suburban environment with dense vegetation. Besides, during the study duration; there was an active construction site located adjacent to the sampling area, which may have contributed to formation of water puddles and eventually providing natural breeding sites for Ae. albopictus to oviposit. This study however, with its limited data for indoor population for AU2, Keramat showed that the ratio for Ae. albopictus is ten times higher than Ae. aegypti in indoor setting. Nonetheless, it may be possible that the presence of a very low number of

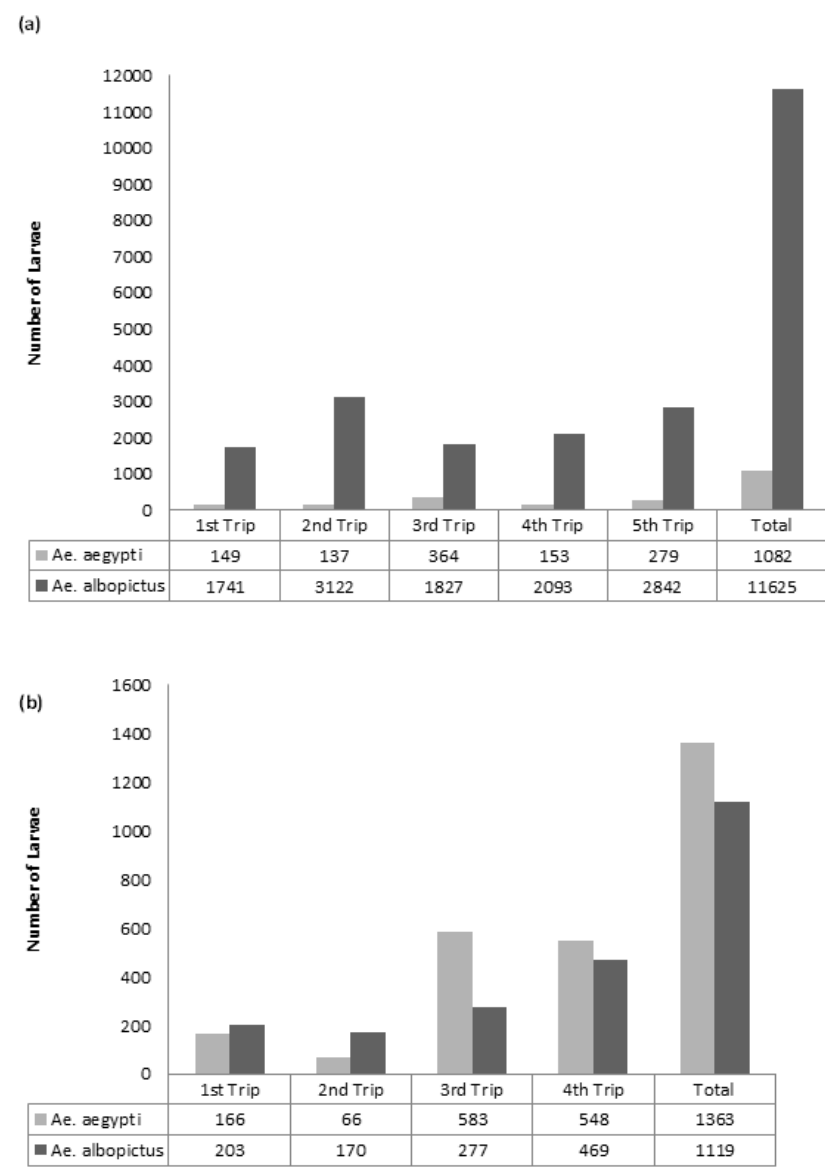

Figure 3 : Total number of Aedes sp. Larvae collected using ovitraps in (a) AU2, Keramat and (b) Seksyen 7, Shah Alam

Ae. aegypti may contribute to this figure. Moreover, in studies where the absence of Ae. aegypti were reported, Ae. albopictus was also found to breed in ovitraps deployed indoors.$^{19,22}$

In Seksyen 7, Shah Alam; the abundance of both species Ae. aegypti and Ae. albopictus is comparable and the $O$ l showed that these two species as an 
Table 3 Mean number of Ae. aegypti and Ae. albopictus and the species ratio collected indoor and outdoor

\begin{tabular}{|c|c|c|c|c|c|c|c|}
\hline \multirow{4}{*}{$\begin{array}{l}\text { Ovitrap } \\
\text { placement } \\
\text { trip }\end{array}$} & \multirow{4}{*}{$\begin{array}{l}\text { Date trap } \\
\text { collected }\end{array}$} & \multicolumn{6}{|c|}{ AU2, Keramat } \\
\hline & & \multicolumn{3}{|c|}{ Indoor } & \multicolumn{3}{|c|}{ Outdoor } \\
\hline & & \multirow{2}{*}{$\begin{array}{c}\text { Ae. aegypti } \\
(\text { Mean } \pm \text { SE) }\end{array}$} & \multirow{2}{*}{$\begin{array}{c}\text { Ae. } \\
\text { albopictus } \\
\text { (Mean } \pm S E)\end{array}$} & \multirow{2}{*}{$\begin{array}{l}\text { Ae. aegypti: } \\
\text { Ae. albopictus }\end{array}$} & \multirow{2}{*}{$\begin{array}{c}\text { Ae. aegypti } \\
(\text { Mean } \pm S E)\end{array}$} & \multirow{2}{*}{$\begin{array}{l}\text { Ae. } \\
\text { albopictus } \\
\text { (Mean } \pm S E)\end{array}$} & Ae. aegypti: \\
\hline & & & & & & & Ae. albopictus \\
\hline $1^{\text {st }}$ Trip & 8-Aug-16 & $0.79 \pm 0.40$ & $7.98 \pm 3.70$ & $1.00: 10.00$ & $2.35 \pm 1.08$ & $28.53 \pm 4.78$ & $1.00: 12.16$ \\
\hline $2^{\text {nd }}$ Trip & 26-Sep-16 & $\mathrm{n} / \mathrm{a}$ & $\mathrm{n} / \mathrm{a}$ & $\mathrm{n} / \mathrm{a}$ & $1.49 \pm 0.51$ & $33.57 \pm 3.64$ & $1.00: 22.79$ \\
\hline $3^{\text {rd }}$ Trip & $10-0 c t-16$ & $\mathrm{n} / \mathrm{a}$ & $\mathrm{n} / \mathrm{a}$ & $\mathrm{n} / \mathrm{a}$ & $3.57 \pm 1.24$ & $17.91 \pm 2.43$ & 1.00:5.02 \\
\hline $4^{\text {th }}$ Trip & $24-0 c t-16$ & $\mathrm{n} / \mathrm{a}$ & $\mathrm{n} / \mathrm{a}$ & $\mathrm{n} / \mathrm{a}$ & $1.44 \pm 0.52$ & $20.32 \pm 2.59$ & $1.00: 13.68$ \\
\hline \multirow[t]{2}{*}{$5^{\text {th }}$ Trip } & 27-Feb-17 & $\mathrm{n} / \mathrm{a}$ & $\mathrm{n} / \mathrm{a}$ & $\mathrm{n} / \mathrm{a}$ & $2.82 \pm 0.92$ & $28.71 \pm 2.89$ & $1.00: 10.19$ \\
\hline & & \multicolumn{6}{|c|}{ Seksyen 7, Shah Alam } \\
\hline $1^{\text {st }}$ Trip & 29-Aug-16 & $1.21 \pm 1.14$ & $0.36 \pm 0.36$ & $3.40: 1.00$ & $2.00 \pm 0.71$ & $2.92 \pm 0.90$ & $1.00: 1.46$ \\
\hline $2^{\text {nd }}$ Trip & $17-O c t-16$ & $0.96 \pm 0.70$ & $0.85 \pm 0.85$ & $1.14: 1.00$ & $0.64 \pm 0.30$ & $2.31 \pm 1.28$ & $1.00: 3.61$ \\
\hline $3^{\text {rd }}$ Trip & $31-0 c t-16$ & $19.74 \pm 7.43$ & 0 & $\mathrm{n} / \mathrm{a}$ & $1.98 \pm 1.38$ & $4.25 \pm 1.32$ & $1.00: 2.14$ \\
\hline $4^{\text {th }}$ Trip & 14-Nov-16 & $7.33 \pm 4.35$ & $3.56 \pm 2.01$ & $2.06: 1.00$ & $5.47 \pm 2.17$ & $5.83 \pm 1.66$ & $1.00: 1.07$ \\
\hline
\end{tabular}

indoor and outdoor breeder respectively. Extensive ovitrap and larval surveys in many urban and suburban areas in peninsular Malaysia ${ }^{24,25}$ reported that although these two species can be found both indoors and outdoors, Ae. aegypti was predominantly found to be dominant indoors and Ae. albopictus to be dominant outdoors.

Although single infestation of either Ae. aegypti or Ae. albopictus is more frequent for ovitraps deployed indoor and/or outdoor, a consistent trend of mixed breeding of the two species was also observed especially for the ovitraps deployed outdoors. Several reports have indicated the mixed infestations of both species in ovitraps deployed in Selangor, Kuala Lumpur and Penang. 9,13,26 The frequency of either species was influenced by placement of the traps, with Ae. aegypti recorded a higher frequency than Ae. albopictus for ovitraps set indoor and vice versa. Mixed infestations were found in both our study areas which was from 5.3\% to $50 \%$. Other studies reported that mixed infestation in different localities in Kuala Lumpur and Selangor was from $3.03 \%$ to $32.0 \%{ }^{9,13}$

In conclusion, this study indicates that Ae. aegypti and Ae. albopictus still remain as dominant indoor and outdoor breeders accordingly. Also, ovitrap is a sensitive tool to attract gravid females of more than one Aedes species to oviposit.

\section{ACKNOWLEDGEMENTS}

The authors thank the Director-General of Health, Malaysia and the Director, Institute for Medical Research (IMR), for permission to publish this study. This study was supported by study grant from the Ministry of Health, Malaysia. We acknowledge the Wolbachia team members from the Medical Entomology Unit, IMR particularly Faiz A, Muhammad Irfan Norman FR, Muhammad Kamarul Ridhuan G, Thohir $H$, Siti Nor Syazwani A, Nur Syamimi HS, Nur Ruqqayah MM and Nur Zatil Aqmar MZ for their technical assistance in collecting and identifying the mosquitoes.

\section{REFERENCES}

1. Preiser W. Tropical virus not only in the tropics. Treatment, epidemiology and diagnosis of tropical viral infections. Pharm Unserer Zeit 2010; 39:34-40.

2. Sutton RNP. Why bother with arboviruses? J Infect 1985; 11:99-102.

3. Howard CR. Viral haemorrhagic fevers: properties and prospects for treatment and prevention. Antiviral Res 1984; 4:169-85.

4. Halstead SB. Selective primary health care: strategies for control of disease in the developing world. XI. Dengue. Rev Infect Dis 1984; 6:251-64. 
5. World Health Organization. Global strategy for dengue prevention and control, 2012-2020.; 2012.

6. MOH. Kenyataan akhbar Ketua Pengarah Kesihatan Malaysia: situasi semasa demam denggi, chikungunya dan Zika di Malaysia untuk tahun 2017. Kenyataan Akhbar.

www.moh.gov.my/index.php/database_stores/ attach_download/337/965. Published 2017.

7. Rattanarithikul R, Panthusiri P. Illustrated keys to the medically important mosquitos of Thailand. Southeast Asian J Trop Med Public Health 1994; 25 Suppl 1:1-66.

8. Chareonviriyaphap T, Akratanakul P, Nettanomsak S, Huntamai S. Larval habitats and distribution patterns of Aedes aegypti (Linnaeus) and Aedes albopictus (Skuse), in Thailand.

Southeast Asian J Trop Med Public Health 2003; 34:529-535.

9. Chen CD, Nazni WA, Lee HL, et al. Mixed breeding of Aedes aegypti (L.) and Aedes albopictus Skuse in four dengue endemic areas in Kuala Lumpur and Selangor, Malaysia. Trop Biomed 2006; 23:224-7.

10. Rozilawati H, Zairi J, Adanan CR. Seasonal abundance of Aedes albopictus in selected urban and suburban areas in Penang, Malaysia. Trop Biomed 2007; 24:83-94.

11. Dieng H, Saifur RGM, Hassan AA, et al. Indoorbreeding of Aedes albopictus in northern peninsular Malaysia and its potential epidemiological implications. PLoS One 2010; 5 (7):e11790.

12. Lim K, Sit N, Norzahira R, et al. Dengue vector surveillance in insular settlements of Pulau Ketam, Selangor, Malaysia. Trop Biomed 2010; 27:185-92.

13. Rozilawati H, Tanaselvi K, Nazni WA, et al. Surveillance of Aedes albopictus Skuse breeding preference in selected dengue outbreak localities, peninsular Malaysia. Trop Biomed 2015; 32:49-64.

14. Arunachalam N, Samuel PP, Hiriyan J, Gajanana A. A comparative study on sampling techniques for Aedes aegypti (Diptera: Culicidae) surveillance in Madurai, South India. Trop Biomed 1999; 16:25-9.

15. Lee HL. Aedes ovitrap and larval survey in several suburban community in Selangor. Mosq Borne Dis Bull 9(1). 1992:9-15.

16. Beech CJ, Nagaraju J, Vasan SS, et al. Risk analysis of a hypothetical open field release of a self-limiting transgenic Aedes aegypti mosquito strain to combat dengue. Asia-Pacific J Mol Biol Biotechnol 2009; 17:99-111.

17. Focks D. A review of entomological sampling methods and indicators for dengue vectors. Dengue Bull 2004; 28:208389.

18. $\mathrm{MOH}$. Guidelines on the Use of Ovitrap for Aedes Surveillance. Kuala Lumpur; 1997.

19. Noor Afizah A, Mahirah MN, Khairul Asuad M, Nazni WA, Lee HL. Absence of Aedes aegypti (L.) on an ecological island: competitive exclusion? Southeast Asian J Trop Med Public Health 2015; 46: 850-6.

20. Mahadevan S, Cheong WH, Hassan A. Vectors of dengue and dengue haemorrhagic fever in West Malaysia. Kuala Lumpur: Institute for Medical Research; 1973.

21. Tham AS. Surveillance of mosquitoes. In: F.S.P. $\mathrm{Ng} \&$ H.S. Yong, eds. Mosquito and Mosquito Borne Disease. Kuala Lumpur: Akademi Sains Malaysia; 2000.

22. Wan-Norafikah $\mathrm{O}$, Chen $\mathrm{CD}$, Soh $\mathrm{HN}$, Lee $\mathrm{HL}$, Nazni WA, Sofian-Azirun M. Surveillance of Aedes mosquitoes in a university campus in Kuala Lumpur, Malaysia. Trop Biomed 2009; 26:206-15.

23. Saleeza SNR, Norma-Rashid Y, Sofian-Azirun M. Mosquitoes larval breeding habitat in urban and suburban areas, Peninsular Malaysia. Int J Biol Vet Agric Food Eng. 2011; 5:72-6.

24. Lee HL. A nationwide resurvey of the factors affecting the breeding of Aedes aegypti (L.) and Aedes albopictus (Skuse) (Diptera: Culicidae) in urban towns of peninsular Malaysia-1988-1989. Trop Biomed 1991; 8:185-9.

25. Lee HL. Sequential sampling: its application in ovitrap surveillance of Aedes (Diptera: Culicidae) in Selangor, Malaysia. Trop Biomed 1992; 9:29-34.

26. Wan Norafikah O, Nazni WA, Shafa' Ar-Ko 'ohar $\mathrm{S}$, et al. Ovitrap surveillance and mixed Infestation of Aedes aegypti (Linnaeus) and Aedes albopictus (Skuse) in northern region and southern region of Malaysia. Health Environ $\mathrm{J}$ $2011 ; 2$. 